\section{APPLICATION OF THE CFD SOFTWARE FOR MODELING THERMAL COMFORT IN SPORT HALL}

MIROSLAV RIMAR, ANDRII KULIKOV, MARCEL FEDAK,
SERHII KHOVANSKYI, IVAN PAVLENKO

Technical University of Kosice, Faculty of Manufacturing

Technologies with a seat in Presov, Department of Process Technique, Presov, Slovak Republic

Sumy State University, Faculty of Technical Systems and Energy Efficient Technologies, Department of Applied Hydro and Aeromechanics, Department of General Mechanics and Machine Dynamics, Sumy, Ukraine

DOI: 10.17973/MMSJ.2020_03_2019023 e-mail: miroslav.rimar@tuke.sk

The building as a single energy system represents not just a set of elements of fencing structures and engineering equipment, but a certain combination of them. The object under the study was the sports hall. During the simulation the calculation model of energy, viscous and radiation were chosen. Comparison of thermal conditions of the premises with different heating methods confirmed that direct heating of the halls is a more appropriate form comparing to the radiator heating. The developed models allow to carry out an estimation of observance of comfortable conditions in the premises, to carry out the analysis of the thermal balance of the premises

KEYWORDS CFD, HRV, heating, natural convection, ANSYS

\section{INTRODUCTION}

According to the International Energy Agency, the majority of the world's population approximately $80 \%$ of the time is located on different premises, which consumed around $40 \%$ of world energy production. The building as a single energy system represents not just a set of elements of fencing structures and engineering equipment, but a certain combination of them, which gives the entire system as whole new qualities, which are absent in each individual element [Aste 2017]. Provision of certain thermal conditions in areas of a building involves the coordination of interacted and interconnected heat flows in a complex energy system characterized by a variety of constituent elements (enclosing structures and engineering systems) [Gul 2018]. Each of these components can be as an energy consumer and as producer [Duplakova 2016]. Solving the problem of increasing the energy efficiency requires taking into account with a large number of factors and it is necessary to improve the methods of evaluation and control of the energy efficiency level of the operation of heat supply systems [Stefanenko 2018].

According to world practice, in order to increase the efficiency of heat energy utilization in buildings, energy audits are carried out [Panda 2014]. These audits require a large number of laborintensive measurements, thermal calculations, comparison of different options and the choice of the most efficient one [Zajac 2004]. Therefore, in world practice, numerical computer simulation methods are widely used. They allow to considering a large number of options during the design and choose the best terms of energy efficiency, comfort and safety [Krenicky 2010, Murcinkova 2013]. Also, these methods allow to simulate existing objects, evaluate the effectiveness of their work and find ways of modernization [Sotnik 2015].

\section{MATERIAL AND METHODS}

The object under the study was the sports hall of the Faculty of manufacturing technologies with the seat in Presov. For a numerical experiment, a three-dimensional model of the room was created and approximated to real conditions [Pavlenko 2019].

Following simplifications (idealization of the model) were taken [Schachner 2018]: the influence of small objects of the interior was not taken into account, not taking into account the presence of heating pipes. The heat sources of the hall are eight radiators.

The calculated area in this task is the internal volume of the sport hall, including its filling objects. An unstructured hexagonal grid was chosen for the calculated area, which accounted for approximately 1 mil cells. This type of grid was chosen due to the fact that this geometric model of the calculated region represents a set of sufficiently correct elementary volumes for which an ordered block structure is acceptable. An example of the generated mesh is in Figure 1.

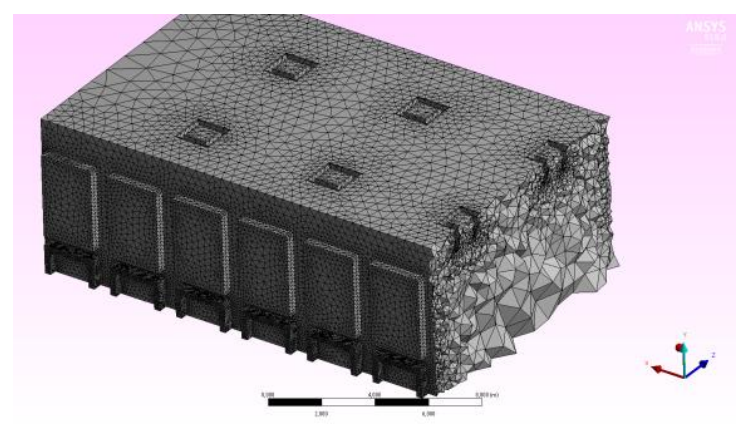

Figure 1. Mesh of the mode

According to the literature the temperature in the sport hall must be around $18^{\circ} \mathrm{C}$ to satisfy the conditions of the comfort being [Straka 2016]. The outdoor temperature was $0^{\circ} \mathrm{C}$ what is appropriate for the winter conditions in the eastern Slovakia climate [Flimel 2015]

Thermal characteristics of the windows, walls, floor and ceiling were chosen according to their technical documentation.

Table 1. Boundary conditions of the simulation

\begin{tabular}{cccc}
\hline № & Boundary & Condition & Value \\
& & & \\
\hline 1 & Floor & Heat Transfer & $0.37\left(6^{\circ} \mathrm{C}\right)$ \\
& & Coefficient & $\mathrm{W} / \mathrm{m}^{2} \mathrm{~K}$ \\
2 & \multirow{2}{*}{ Ceiling } & Heat Transfer & $0.6\left(0^{\circ} \mathrm{C}\right)$ \\
& & Coefficient & $\mathrm{W} / \mathrm{m}^{2} \mathrm{~K}$ \\
\hline
\end{tabular}




\begin{tabular}{|c|c|c|c|}
\hline 3 & Walls & $\begin{array}{c}\text { Heat Transfer } \\
\text { Coefficient }\end{array}$ & $\begin{array}{l}1.2\left(0^{\circ} \mathrm{C}\right) \\
\mathrm{W} / \mathrm{m}^{2} \mathrm{~K}\end{array}$ \\
\hline 4 & Windows & $\begin{array}{c}\text { Heat Transfer } \\
\text { Coefficient }\end{array}$ & $\begin{array}{l}1.6\left(0^{\circ} \mathrm{C}\right) \\
\mathrm{W} / \mathrm{m}^{2} \mathrm{~K}\end{array}$ \\
\hline 5 & Doors & Adiabatic & - \\
\hline 6 & Radiators & Heat flux & $1000 \mathrm{~W}$ \\
\hline 7 & Inlets & Velocity inlet & $\begin{array}{c}0.25 \mathrm{~m} / \mathrm{s} \\
\left(20^{\circ} \mathrm{C}\right)\end{array}$ \\
\hline 8 & Outlets & Pressure outlet & - \\
\hline
\end{tabular}

During the simulation the calculation model of energy, viscous and radiation were chosen [Dobakova 2018]. Model of gravity was used according to the conditions of the process of free (natural) convection in a closed volume, which could be calculated due to the action of mass (volume) forces [Ascione 2017]. The model of air displacement in the calculated region was described by the Navier-Stokes equations averaged over the Reynolds number [Mikeska 2015].

\section{SIMULATION}

The simulation of the original heating system of the research object was made in ANSYS 19.0. As a setting for FLUENT it was used the energy equation model, standard K-epsilon model and radiation p1 model [Jandacka 2015]. The results of the simulation are presented at the Figure 2. The original heating system simulation means the heating via classic radiators which are installed below each window at the wall in front of the enter/exit. According to the conditions of the natural convection the boundary conditions for inlets and outlets were chosen as for ceiling.

The upper part of the Figure shows the temperature contours across the hall in $\mathrm{ZY}$ axis. The lower part of the Figure shows the temperature contours across the hall in XY axis [Varga 2017]. According to the simulation results the volume average temperature inside the sport hall is approximately $292 \mathrm{~K}$. The main heat source are classic radiators with the $1000 \mathrm{~W} / \mathrm{m} 2$ power. The major part of heat is going out through the walls (30\%), windows (40\%) and ceiling (30\%) as they are in direct contact with the outside air. The temperature difference between the floor and $2 \mathrm{~m}$ high air layer is $0.8^{\circ} \mathrm{C}$ what is appropriate according to the EN 12831.

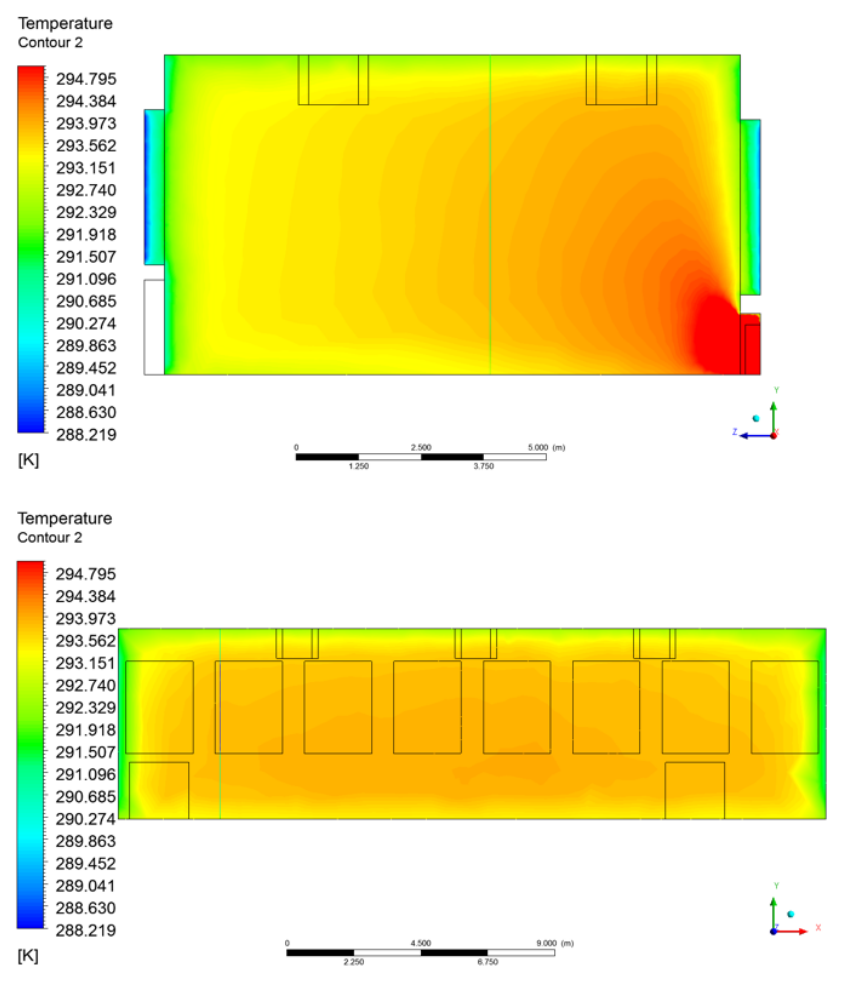

Figure 2. Original simulation results. Temperature contours

The graphic results of air streams of natural convection are at the Figure 3.
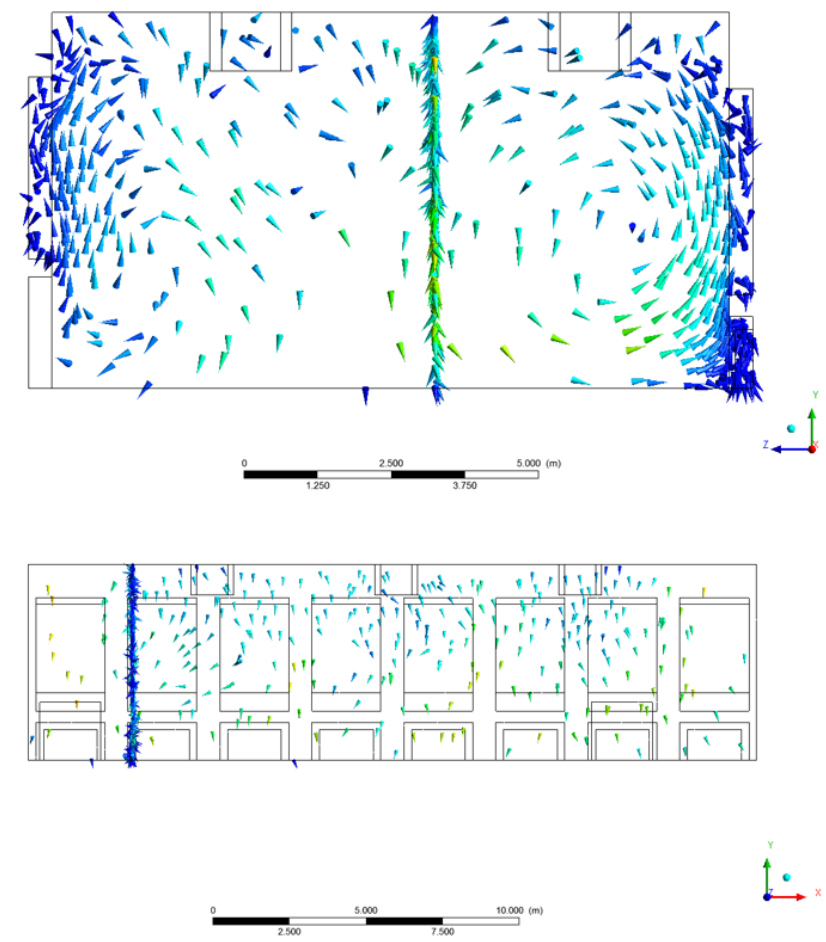

Figure 3. Original simulation results. Velocity vectors

The upper part of the Figure shows the air velocity vectors across the hall in ZY axis. The lower part of the Figure shows the air vectors across the hall in $X Y$ axis. According to the simulation results the sport hall can be divided by two main parts of the air flow type to understand air circulation. 


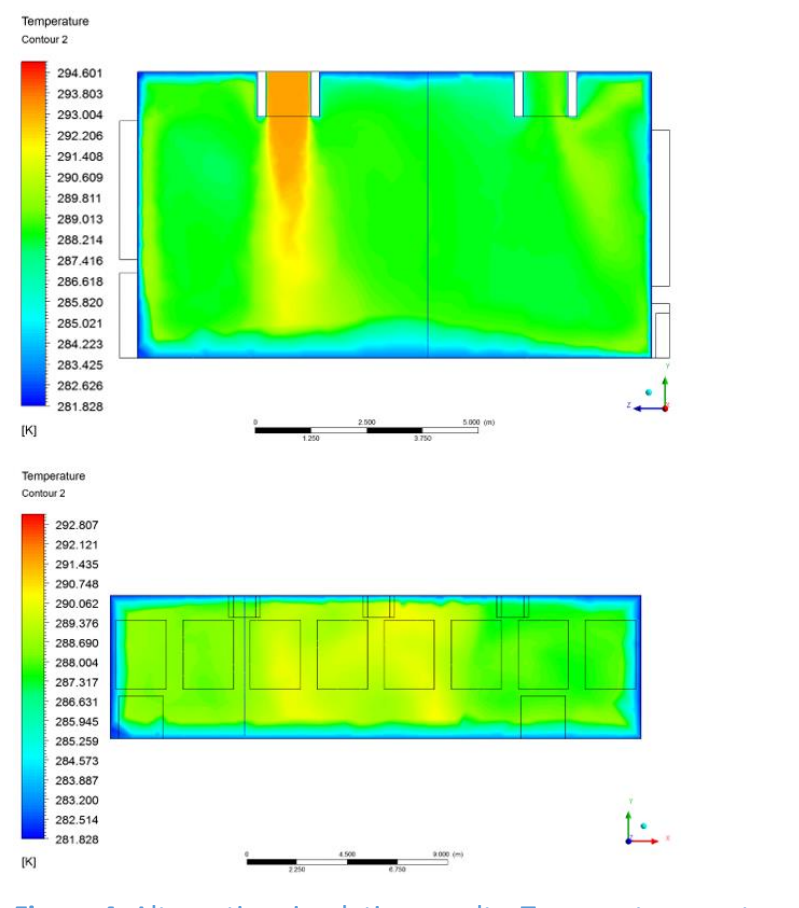

Figure 4. Alternative simulation results. Temperature contours

The first part represents area form the vertical axis to the wall with radiators. In this part the due to natural convection process air which heated near the radiators are going up to the ceiling where it cooling due to the temperature differences inside and outside the hall. After a heated air cooled it going down where it divided by two parts. The first one goes to the radiator where it heated again, while the other one goes to the opposite wall and in such way make a second circulation area in the hall.

The second part represent the air circulation in the left part, according to the Figure 3 . In this part the circulation is forced by the cooler air from the right part. Due to radiators location the left part of the hall has slightly lower temperature so air at this part still have lower temperature and higher density comparing with the air in the right part what results convection at this part of the hall.

As an alternative heating system it was proposed the heat recovery ventilation with the option of preheating fresh air. The simulation of the alternative heating system of the research object was made in ANSYS 19.0. As a setting for FLUENT it was used the energy equation model, standard K-epsilon model and radiation $p 1$ model. The results of the simulation are at the Figure 4 . The upper part of the Figure shows the temperature contours across the hall in ZY axis. The lower part of the Figure shows the temperature contours across the hall in $X Y$ axis. According to the simulation results the volume average temperature inside the sport hall is approximately $291 \mathrm{~K}$. The main heat source is HRV unit.

The major part of heat is going out through the walls (30\%), windows (40\%) and ceiling (30\%). The temperature difference between the floor and $2 \mathrm{~m}$ high air layer is $0.3^{\circ} \mathrm{C}$ what is appropriate according to the EN 12831.

Nevertheless, the alternative heating system has lower power consumption $12 \mathrm{KW}$ comparing with the approximately $16 \mathrm{KW}$ of the original system.

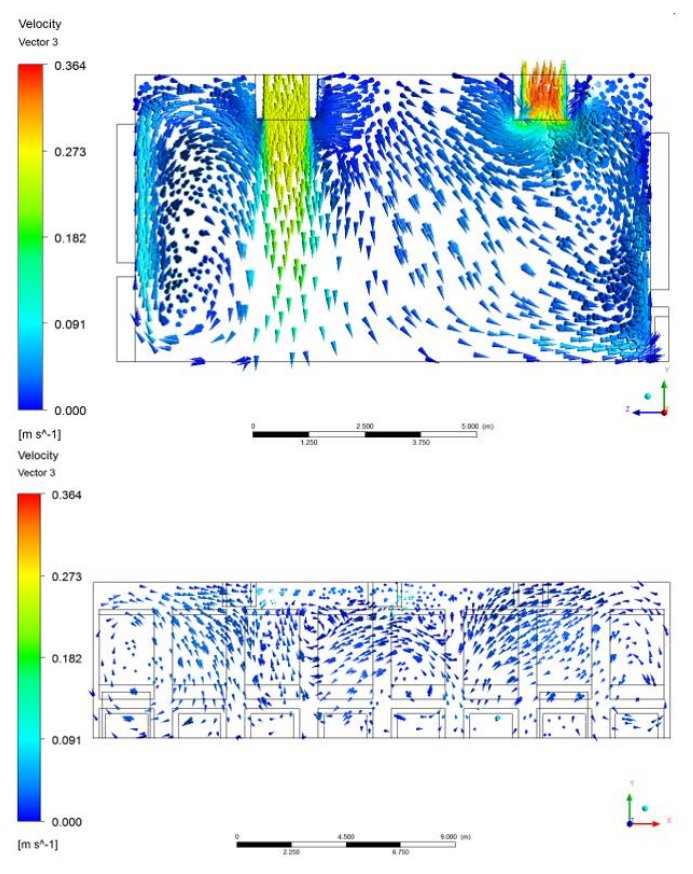

Figure 5. Alternative simulation results. Velocity vectors

The upper part of the Figure shows the air velocity vectors across the hall in $\mathrm{ZY}$ axis. The lower part of the Figure shows the air vectors across the hall in $\mathrm{XY}$ axis. According to the simulation results the sport hall can be divided by two main parts of the air flow type to understand air circulation. Obviously, that whole air circulation map has totally change comparing with original state.

The first part represents area form the inlet nozzles to the wall with doors. In this part the heated air flows into the hall through the nozzles installed at the ceiling. The air velocity of the fresh air at the inlet is $0,25 \mathrm{~m} / \mathrm{s}$ while at the $2 \mathrm{~m}$ high level it reduces to $0.1-0.15 \mathrm{~m} / \mathrm{s}$, what is appropriate according to the EU norms. At the floor the stream divided by two part. One of this part circulate at the volume between the inlet stream and wall while the other one goes to the opposite wall and in such way make a second circulation area in the hall.

The second part represent the air circulation in the right part, according to the Figure 5 . In this part the circulation is forced by the fresh air from the inlet stream and also owing to the circulated air. The main process of the right part is removal of the exhausted air from the sport hall.

Owing to the higher intensity and direct distribution of the heat flows to the ground level the alternative heating system is more effective as original one.

\section{MEASUREMENTS AND DISCUSSION}

A series of measurements were made to approve the results of the simulation. 


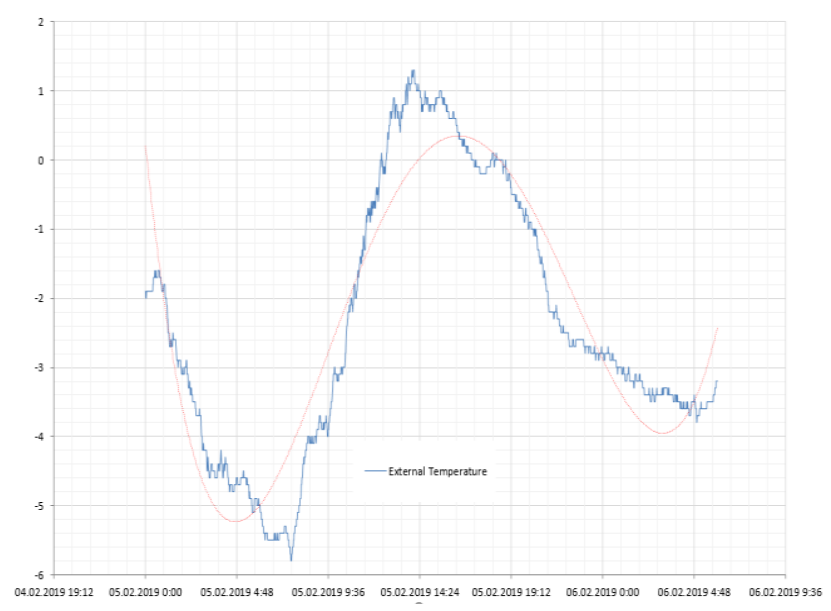

Figure 6. External day temperature

To validate the results of the simulation was chosen a day $-2 \mathrm{nd}$ of February 2018 as the exterior air temperature in working hours was the approximately the same $-2-0.5^{\circ} \mathrm{C}$ (average $0^{\circ} \mathrm{C}$ ).

Internal thermometer was placed on the wall at $1.6 \mathrm{~m}$ high between the windows. According to the measured data average temperature inside the hall was $17-18^{\circ} \mathrm{C}$ during the day. According to the measured data was chosen the boundary condition parameters as well as the validation of the original heating system.

\section{CONCLUSIONS}

The designed model of the sport hall of the Technical University in Košice in the ANSYS software system allow us to estimate the parameters of the thermal state, namely: to obtain the distribution of temperature fields, fields of air velocity; determine the value of heat fluxes on the surfaces of structures; establish the presence of stagnant zones and vortices in the premises.

2. The developed models allow to carry out an estimation of observance of comfortable conditions in the premises, to carry out the analysis of the thermal balance of the premises, as well as calculations of the efficiency for different methods of regulation and evaluation of energy saving measures.

2. Comparison of thermal conditions of the premises with different heating methods confirmed that direct heating of the halls is a more appropriate form comparing to the radiator heating. HRV units distribute warm fresh air directly to the necessary areas (human etc.) so there is no need to heat the ceiling.

\section{ACKNOWLEDGMENTS}

This work was supported by the Slovak Research and Development Agency under the contract No. APVV-16-0192

The article was carried out at the Faculty of Manufacturing Technologies with a seat in Presov of Technical University of Kosice and supported by the National Scholarship Programme of the Slovak Republic within the research projects "Research of Unsteady Temperature Condition of Premises Heated by Lowgrade Renewable Energy Sources" and "Identification of Parameters for Technological Equipment using Artificial Neural Networks".

\section{REFERENCES}

[Ascione 2017] Ascione, F. Energy conservation and renewable technologies for buildings to face the impact of the climate change and minimize the use of cooling. Solar Energy, 2017, Vol. 154, pp. 34-100.

[Aste 2017] Aste, N., Manfren, M. and Marenz, G. Building Automation and Control Systems and performance optimization: A framework for analysis. Renewable and Sustainable Energy Reviews, 2017, Vol. 75, pp. 313-330.

[Dobakova 2018] Dobakova, R., Brestovič, T., Jasminská, N. Determination of Heat Exchange on the Internal Side of Pipelines in District Heating Systems. Global Journal of Advanced Engineering Technologies and Sciences, 2018, Vol. 5, No. 11 pp. 10-14. ISSN 2349-0292.

[Duplakova 2016] Dupláková, D., Radchenko, S., Knapčíková, L., Hatala, M. Simulation as ergonomic tool for evaluation of illumination quality in engineering. Acta Simulatio, 2016, Vol. 2, No. 3, pp. 1-7. ISSN 1339-9640.

[Flimel 2015] Flimel, M., Dupláková, D. Application of the Ergonomic Redesign in Terms of Workplace Rationalization. Applied Mechanics and Materials, 2015, Vol. 718, pp. 239-244. ISBN 978-3-03835-377-5.

[Gul 2018] Gul, E., Wang, J., Zhang, G. Simulation and Optimization Model for Energy Efficient Building and Environmental Assessment. In: 2nd IEEE Conference on Energy Internet and Energy System Integration, El2 2018 - Proceedings, 19 December 2018; Beijing; China, 2018.

[Jandacka 2015] Jandacka, J. et al. Optimization principle of operating parameters of heat exchanger by using CFD simulation. In: 10th International Conference on Experimental Fluid Mechanics EFM 2015, Code 121087, 2015.

[Krenicky 2010] Krenicky, T. The Monitoring of Technical Systems Operation Using Virtual Instrumentation. In: Strojarstvo extra. No. 5 (2010), pp. 25/1-25/2. ISSN 1335-2938. (in Slovak)

[Mikeska 2015] Mikeska, T., Fan, J. Full scale measurements and CFD simulations of diffuse ceiling inlet for ventilation and cooling of densely occupied rooms, Energy and Buildings, 2015, Vol. 107, Art. No. 5976, pp. 59-67. ISSN 0378-7788.

[Murcinkova 2013] Murcinkova, Z., Krenicky, T. Implementation of virtual instrumentation for multiparametric technical system monitoring. In: SGEM 2013: 13th Int. Multidisciplinary Sci. Geoconf. Vol.1: 16-22 June, 2013, Albena, Bulgaria. Sofia: STEF92 Technology, 2013, pp. 139-144. ISBN 978-954-91818-9-0.

[Panda 2014] Panda, A., et. al. Progressive technology diagnostic and factors affecting to machinability. Applied Mechanics and Materials, 2014, vol. 616, pp. 183-190. ISSN 1660-9336.

[Pavlenko 2019] Pavlenko, I., Trojanowska, J., Ivanov, V., Liaposhchenko, O. Scientific and methodological approach for the identification of mathematical models of mechanical systems by using artificial neural networks. In: International Conference on Innovation, Engineering and Entrepreneurship, HELIX 2018. Lecture Notes in Electrical Engineering, 2019, Vol. 505, pp. 299-306.

[Schachner 2018] Schachner, S., Sauter, T. Comparison of energy harvesting concepts for heating, ventilation and air conditioning systems. In: Proceedings of IECON 2018 - 44th Annual Conference of the IEEE Industrial Electronics Society, Washington, USA, 20 October 2018, pp. 6235-6240.

[Sotnik 2015] Sotnik, N., Khovanskyy, S., Grechka, I., Panchenko, V., Maksimova, M. Simulation of the thermal state of the premises with the heating system "heat-insulated floor». Eastern-european journal of enterprise technologies, 2015, Vol. 6, No. 5, pp. 22-27. 
[Stefanenko 2018] Stefanenko, I.V., Sergina, N.M. To a Question of Energy Saving in Ventilation Systems of Industrial Buildings. In: International Multi-Conference on Industrial Engineering and Modern Technologies 2018; Vladivostok; Russian Federation; 2 October 2018. IOP Conference Series: Materials Science and Engineering, 2018, Vol. 463, Issue 3, 032039.

[Straka 2016] Straka, L., Gerková, J., Hašová, S. Proposal of preventive maintenance plan of experimental equipment. Key Engineering Materials, 2016, Vol. 669, pp. 523-531.

[Varga 2017] Varga, A., Kizek, J., Vaszi, Z. Mathematical modelling of the throughput of compressor station. Selected problems in the transport of natural gas. Zagreb: University of Zagreb, Faculty of Metallurgy, 2017, pp. 130-160. ISBN 978-9537082-28-4

[Zajac 2004] Zajac, J., Čorný, I. Monitoring of processing fluids, Science Report, Kielce, 2004, pp. 215-229.

\section{CONTACTS}

Prof. Ing. Miroslav Rimar, CSc., Ing. Marcel Fedak, Ph.D., Ing. Andrii Kulikov Ph.D.

Technical University of Kosice,

Faculty of Manufacturing Technologies with a seat in Presov

Department of Process Technique

31 Sturova,080 01 Presov, Slovak Republic

tel.: +421 556026341

Assoc. Prof. Serhii Khovanskyi, Ph.D.

Assoc. Prof. Ivan Pavlenko, Ph.D.

Sumy State University

Faculty of Technical Systems and Energy Efficient Technologies Department of Applied Hydro and Aeromechanics,

Department of General Mechanics and Machine Dynamics,

2 Rymskogo-Korsakova St., 40007 Sumy, Ukraine

tel.: +38 0994959745

e-mail: miroslav.rimar@tuke.sk, marcel.fedak@tuke.sk, andrii.kulikov@tuke.sk, s.khovanskiy@pgm.sumdu.edu.ua, i.pavlenko@omdm.sumdu.edu.ua 